\title{
TREATMENT OF PEMPHIGUS VULGARIS AND PEMPHIGUS FOLIACEUS: EXPERIENCE WITH 71 PATIENTS OVER A 20 YEAR PERIOD*
}

\author{
Nurimar C. FERNANDES(1) \& Mauricio PEREZ(2)
}

\begin{abstract}
SUMMARY
Forty one cases of pemphigus vulgaris and thirty cases of pemphigus foliaceus were investigated at Hospital Universitário Clementino Fraga Filho from 1978 to 1999. They were divided into two treatment groups: one group received up to $100 \mathrm{mg}$ of oral prednisone daily and the other group received $>120 \mathrm{mg}$ daily. The dose up to $100 \mathrm{mg}$ provided good initial control of pemphigus vulgaris and pemphigus foliaceus and did not increase the mortality rate associated to disease. The dose $>120 \mathrm{mg}$ induced higher morbidity. These data allowed us to establish a regimen of oral prednisone (1-2 mg/kg/daily) with maximum of $120 \mathrm{mg}$ daily in the treatment of pemphigus vulgaris and pemphigus foliaceus.
\end{abstract}

KEYWORDS: Pemphigus vulgaris; Pemphigus foliaceus; Treatment.

\section{INTRODUCTION}

Systemic corticosteroids are the most useful drugs for the treatment of pemphigus ${ }^{6}$. Some patients have mild disease manifested by only a few indolent lesions that can be controlled simply with low doses of corticosteroids. Others have fulminating disease that cannot be controlled even with massive doses. Efforts are rarely made to correlate therapeutic results with extent or activity of disease even though the severe cases require larger doses of corticosteroids and have a higher mortality. The terms activity, extent and severity are poorly defined; as a consequence, the evaluation of therapeutic results in published studies must be limited to an analysis of two basic variables: mortality and remission. The methodology used to define and study adverse effects is so wide and poorly described in most studies that no attempt have been made to analyze $\mathrm{it}^{1,4,6}$.

We present a retrospective study of the clinical course of pemphigus vulgaris and pemphigus foliaceus treated with prednisone.

\section{MATERIAL AND METHODS}

41 cases of pemphigus vulgaris and 30 cases of pemphigus foliaceus were investigated at Hospital Universitário Clementino Fraga Filho, Rio de Janeiro, from 1978 to $1999^{12}$ with the following criteria:

1. histological confirmation; the direct immunofluorescence was performed only in case of doubtful diagnosis; the indirect immunofluorescence test is not routinely performed in the follow up of pemphigus cases ${ }^{4}$
2. therapy initiated with oral prednisone: a) $2 \mathrm{mg} / \mathrm{kg} /$ daily in the extensive pemphigus vulgaris that is with involvement of the mucous membranes and skin $^{9}$ or rapidly progressive skin disease; b) $2 \mathrm{mg} /$ $\mathrm{kg} /$ daily in the extensive pemphigus foliaceus that is rapidly progressive skin disease; c) $1 \mathrm{mg} / \mathrm{kg} /$ daily in pemphigus vulgaris when oral lesions were the only clinical manifestations; d) $1 \mathrm{mg} / \mathrm{kg} /$ daily in not extensive and progressive skin disease of pemphigus foliaceus ${ }^{8}$; e) $1 \mathrm{mg} / \mathrm{kg} /$ daily for both pemphigus in the presence of relative contraindications to corticosteroids: peptic ulcer, diabetes, cataracts, osteoporosis, hypertension, tuberculosis, obesity, glaucoma, old age.

3. both groups were kept on prednisone for 4-6 weeks to achieve a state in which no new lesions were appearing and old lesions were healing (control phase); then it was gradually tapered (10 mg every ten days interval) until $20 \mathrm{mg}$ daily was reached. From this stage on, the following schedule was employed: $20 \mathrm{mg}$ ( 6 months); $10 \mathrm{mg}$ (6 months); $5 \mathrm{mg}$ (6 months); $2.5 \mathrm{mg}$ (6 months). The drug could be stopped when a state of no new lesions were observed in the last twelve months.

4. the 20 cases submitted to a combined treatment schedule with azathioprine (pemphigus vulgaris), dapsone (pemphigus vulgaris) or chloroquine (pemphigus foliaceus) were not included in the present study; these situations were the following:

- Patients who were not controlled to initial therapy with prednisone until 10 weeks ${ }^{4}$;

*Hospital Universitário Clementino Fraga Filho, Universidade Federal do Rio de Janeiro, RJ, Brasil.

(1) Associate Professor of Dermatology, Departamento de Clínica Médica, Faculdade de Medicina, UFRJ, RJ, Brasil.

(2) Epidemiologist, Núcleo de Estudos em Saúde Coletiva (NESC), Faculdade de Medicina, UFRJ, RJ, Brasil.

Correspondence to: Nurimar C. Fernandes, Rua Alexandre de Gusmão 28 apto. 201, 20520-120 Rio de Janeiro, RJ, Brasil. 
- Patients being treated with prednisone in whom complications developed with its use (psychosis, aseptic necrosis of femur, emotional lability, severe hypertension, uncontrolled diabetes $)^{4}$;

- Patients in whom repeated attempts to taper corticosteroids was associated with recurrence of disease ${ }^{4}$.

5. in a 5-year-follow-up, all cases of pemphigus (vulgaris and foliaceus) were assessed on clinical development of prednisone side effects: infections (impetigo, septicemia, kidney infection, candidiasis, tinea, herpes simplex, zoster, molluscum), hypertension, diabetes, psychosis, Cushing syndrome, cataracts, aseptic necrosis of femur and peptic ulcer. The mortality rates were evaluated in pemphigus vulgaris and foliaceus (each one) considering that this variable depends also on the disease itself.

6. Chi-square (Yates) or Fisher exact test were used whenever appropriate.

\section{RESULTS}

Twenty-eight females and 13 males aged 20 to 80 years had pemphigus vulgaris (Table 1). The initial dose did not influence the response to treatment $(\mathrm{p}>0.05)$ (Table 2$)$ and mortality rate $(\mathrm{p}>0.05)$ (Table 3 ) in these cases.

Table 1

Distribution of cases according to age and sex

\begin{tabular}{cccccc}
\hline & \multicolumn{2}{c}{$\begin{array}{c}\text { PV } \\
\text { sex }\end{array}$} & \multicolumn{2}{c}{$\begin{array}{c}\text { PF } \\
\text { sex }\end{array}$} & \\
\cline { 2 - 5 } Age & Male & Female & Male & Female & Total \\
\hline $10-19$ & - & - & 1 & 1 & 2 \\
$20-29$ & 2 & 2 & - & 2 & 6 \\
$30-39$ & 2 & 8 & 6 & 2 & 18 \\
$40-49$ & 4 & 2 & 3 & 1 & 10 \\
$50-59$ & 3 & 4 & 2 & 1 & 10 \\
$60-69$ & 1 & 6 & 5 & 2 & 14 \\
$70-80$ & 1 & 6 & 2 & 2 & 11 \\
\hline Total & 13 & 28 & 19 & 11 & 71 \\
\hline
\end{tabular}

HUCFF-UFRJ (1978-1999); PV - Pemphigus vulgaris; PF - Pemphigus foliaceus

Table 2

Distribution of cases (Pemphigus vulgaris), according to dosage of prednisone and response to treatment

\begin{tabular}{cccc}
\hline \multirow{2}{*}{ Dose } & \multicolumn{2}{c}{ Response } & \\
\cline { 2 - 3 } & Yes & No & Total \\
\hline $80-100$ & 9 & 3 & 12 \\
$>120$ & 21 & 8 & 29 \\
\hline Total & 30 & 11 & 41 \\
\hline
\end{tabular}

HUCFF-UFRJ (1978-1999); p>0.05
Nineteen males and eleven females aged 10 to 80 years had pemphigus foliaceus (Table 1). The initial dose did not influence the response to treatment $(\mathrm{p}>0.05)$ (Table 4$)$ and mortality rate $(p>0.05)$ (Table 5) in these cases. The side effects could be related to larger doses of prednisone $(\mathrm{p}<0.05)$ (Table 6$)$ in both diseases.

\section{DISCUSSION}

In our retrospective study we grouped the patients according to the initial dose of prednisone as other investigators ${ }^{7,9}$; the dose was determined by criteria of extension of skin disease (pemphigus vulgaris and pemphigus foliaceus) and mucous disease (pemphigus vulgaris). The dose higher than $120 \mathrm{mg}$ daily was not more effective in the initial control of pemphigus vulgaris $(\mathrm{p}>0.05)$ [Table 2] and pemphigus foliaceus $(p>0.05$ ) [Table 4]. The dosage up to $100 \mathrm{mg}$ daily provided good initial response in both pemphigus (control phase).

Table 3

Distribution of cases (pemphigus vulgaris) according to mortality

\begin{tabular}{cccc}
\hline \multirow{2}{*}{ Dose } & \multicolumn{2}{c}{ Mortality } & \\
\cline { 2 - 3 } & Yes & No & Total \\
\hline $80-100$ & 0 & 12 & 12 \\
$>120$ & $3(10 \%)$ & 26 & 29 \\
\hline Total & 3 & 38 & 41 \\
\hline HUCFF-UFRJ (1978-1999); $\mathrm{p}>0.05$ & &
\end{tabular}

\section{Table 4}

Distribution of cases (Pemphigus foliaceus), according to dosage of prednisone and response to treatment

\begin{tabular}{cccc}
\hline & \multicolumn{2}{c}{ Response } & \\
\cline { 2 - 3 } Dose & Yes & No & Total \\
\hline $80-100$ & 15 & 7 & 22 \\
$>120$ & 6 & 2 & 8 \\
\hline Total & 21 & 9 & 30 \\
\hline
\end{tabular}

HUCFF-UFRJ (1978-1999); p>0.05

Table 5

Distribution of cases (pemphigus foliaceus) according to mortality

\begin{tabular}{cccc}
\hline \multirow{2}{*}{ Dose } & \multicolumn{2}{c}{ Mortality } & \\
\cline { 2 - 3 } & Yes & No & Total \\
\hline $80-100$ & $2(9 \%)$ & 20 & 22 \\
$>120$ & $1(12 \%)$ & 7 & 8 \\
\hline Total & 3 & 27 & 30 \\
\hline HUCFF-UFRJ (1978-1999); $\mathrm{p}>0.05$ & &
\end{tabular}


Table 6

Distribution of cases according to dosage of prednisone and side effects

\begin{tabular}{|c|c|c|c|c|c|c|c|c|c|}
\hline Dose & Infections & $\begin{array}{l}\text { Hyper- } \\
\text { tension }\end{array}$ & Diabetes & $\begin{array}{c}\text { Cushing } \\
\text { syndrome }\end{array}$ & $\begin{array}{l}\text { Psy- } \\
\text { chosis }\end{array}$ & $\begin{array}{l}\text { Cata- } \\
\text { racts }\end{array}$ & $\begin{array}{l}\text { Aseptic } \\
\text { necrosis } \\
\text { of femur }\end{array}$ & $\begin{array}{l}\text { Peptic } \\
\text { ulcer }\end{array}$ & Tota \\
\hline $80-100$ & 16 & 5 & 6 & 2 & - & - & 1 & 1 & 31 \\
\hline$>120$ & 48 & 7 & 4 & 3 & 2 & 2 & - & - & 66 \\
\hline Toal & 64 & 12 & 10 & 5 & 2 & 2 & 1 & 1 & 97 \\
\hline
\end{tabular}

HUCFF-UFRJ (1978-1999); p<0.05

There is no consensus regarding the initial dosage needed to induce remission in pemphigus vulgaris. Some consider that it should be 200 mg daily or even more ${ }^{6,7}$ because this is life - saving and contributes to long term remission. Other consider that a daily oral prednisone dose of $180 \mathrm{mg}$ is an important cause of treatment related fatality ${ }^{2}$. Many patients are treated with daily steroid doses of $40-80 \mathrm{mg}^{8,12}$. A lack of prospective studies and of well controlled trials contribute to the dilemma over the best initial dose and maintenance theraphy ${ }^{1,3}$.

For pemphigus foliaceus, the Brazilian authors state oral prednisone $(1-1.5 \mathrm{mg} / \mathrm{kg} / \mathrm{daily})^{8}$ or oral triamcinolone $(48 \mathrm{mg} / \mathrm{daily})^{11}$. It is quite impossible to compare our figures because several data are lacking in these papers ${ }^{10,11}$.

In our sample the mortality rate could not be related to the initial maximum dose of prednisone required to induce control in the cases of pemphigus vulgaris $(\mathrm{p}>0.05)$ (Table 3 ) and pemphigus foliaceus $(\mathrm{p}>0.05)$ (Table 5).

The literature contains contradictory reports about the relationship between the initial-dose of prednisone and mortality as well as the effect of initial dosage on the subsequent course of pemphigus vulgaris and foliaceus. These discrepancies are, in part, due to differences in data presentation.

The mortality rates in our cases are in accordance with literature data both for pemphigus vulgaris ${ }^{11}(10 \%)$ (Table 3) and pemphigus foliaceus $^{5,10,11}(9 \%$ to $12 \%$ ) (Table 5). Prior to the use of glucocorticoid therapy, significant mortality was associated with patients having pemphigus; most of the deaths used to occur during the first 2-3 months of therapy ${ }^{7}$. Today it is due to drug associated complications ${ }^{12}$.

In our sample increased morbidity was associated with statistical significance to $>120 \mathrm{mg}$ prednisone $(\mathrm{p}<0.05)$ (Table 6$)$. As the mentioned side effects are complications of therapy, we analyzed both pemphigus together. The infections, hypertension and diabetes were the most frequent complications and could be (one or more) present in the same patient. The two cases of psychosis ${ }^{2}$ and one case of aseptic necrosis of femur were not switched to adjuvant therapy (azathioprine, chloroquine, dapsone) for contraindications (renal impairment, retinopathy and glucose 6 - phosphate dehydrogenase deficiency).

Several authors believe that doses over $120 \mathrm{mg}$ or $180 \mathrm{mg}$ greatly increase treatment related morbidity ${ }^{2,12}$. It seems that it is not merely a high daily dose but the duration for which it is given that is important ${ }^{2,6}$.

Mortality, morbidity and the length of clinical remission remain for some authors ${ }^{12}$ the best measures of the efficacy of a therapeutic regimen. We decided not to evaluate the lenght of clinical remission because the patient's compliance intervenes with relapse rates.

It is probable that immediate high dose treatment in every case of pemphigus does not seem absolutely essential anymore ${ }^{14}$. It seems to be possible to try a mild therapy in patients with only a few lesions and slow progression ${ }^{14}$.

\section{CONCLUSIONS}

Our retrospective study indicates that an initial dose up to $100 \mathrm{mg}$ daily of prednisone during 4-6 weeks provides good initial control of pemphigus vulgaris and pemphigus foliaceus; this dosage, besides, does not increase mortality rate associated to disease. On the other hand, higher doses than $120 \mathrm{mg}$ are related to increased morbidity. These results allowed us to establish a regimen of oral prednisone (1-2 $\mathrm{mg} / \mathrm{kg} /$ daily) with maximum of $120 \mathrm{mg}$ daily in the treatment of pemphigus vulgaris and pemphigus foliaceus.

\section{RESUMO}

\section{Tratamento do pênfigo vulgar e pênfigo foliáceo: experiência com 71 pacientes no período de 20 anos}

Quarenta e um casos de pênfigo vulgar e trinta casos de pênfigo foliáceo foram investigados no Hospital Universitário Clementino Fraga Filho, no período 1978-1999. Os pacientes foram divididos em dois grupos de tratamento: um recebendo até $100 \mathrm{mg} / \mathrm{dia}$ de prednisona e o outro grupo $>120 \mathrm{mg}$ diariamente. Com o primeiro esquema, houve bom controle inicial dos pênfigos sem aumento da taxa de mortalidade associada às doenças. A dose acima de $120 \mathrm{mg}$ induziu maior morbidade. Os resultados permitiram estabelecer um esquema de prednisona (1-2 $\mathrm{mg} / \mathrm{kg} / \mathrm{dia}$ ) com dose máxima de $120 \mathrm{mg}$ diários no tratamento dos pênfigos vulgar e foliáceo.

\section{ACKNOWLEDGMENT}

The author is grateful for the cooperation of Dr.Elizabeth V.F.M.Batista, Dr.Cristine Garcia Couto and Dr.Akira Iwamoto (Serviço de Dermatologia, Hospital Universitário Clementino Fraga Filho, UFRJ). 


\section{REFERENCES}

1. ABERER, W.; WOLFF-SCHREINER, E.C.; STINGL, G. \& WOLFF, K. - Azathioprine in the treatment of pemphigus vulgaris. A long-term follow-up. J.Amer. Acad. Derm., 16: 527-533, 1987.

2. AHMED, A.R. \& MOY, R. - Death in pemphigus. J. Amer. Acad. Derm., 7: 221-228, 1982.

3. BYSTRYN, J.C. - Adjuvant therapy of pemphigus. Arch. Derm., 120: 941-951, 1984

4. BYSTRYN, J.C. \& STEINMAN, N.M. - The adjuvant therapy of pemphigus. Arch. Derm., 132: 203-212, 1996.

5. COSTA, P.U.; PATRUS, O.A. \& GUEDES, A.C.M. - Pênfigo foliáceo brasileiro. In: NEVES, J., ed. Diagnóstico e tratamento das doenças infectuosas e parasitárias. Rio de Janeiro, Guanabara Koogan, 1983. p.1176-1181.

6. LEVER, W.F. \& SCHAUMBURG-LEVER, G. - Treatment of pemphigus vulgaris. Results obtained in 84 patients between 1961 and 1982. Arch. Derm., 120: 44-47, 1984.

7. LEVER, W.F. \& WHITE, H. - Treatment of pemphigus with corticosteroids. Results obtained in 46 patients over a period of 11 years. Arch. Derm., 87: 12-26, 1963.
8. MINISTÉRIO DA SAÚDE - Legislação sobre o controle de doenças na área de dermatologia sanitária. Pênfigo foliáceo. 3. ed. Brasília, Fundação Nacional de Saúde, 1992. p. 41-43.

9. MOURELlOU, O.; CHAIDEMENOS, G.C.; KOUSSIDOU, T. \& KAPETIS, E. - The treatment of pemphigus vulgaris. Experience with 48 patients seen over an 11-year period. Brit. J. Derm., 133: 83-87, 1995.

10. PROENÇA, N.G \& CAMPOS, J.A. - Importância do seguimento ambulatorial na redução da letalidade do pênfigo foliáceo sul americano. An. bras. Derm., 47: 47-51, 1972.

11. PROENÇA, N. - Pênfigo foliáceo sul-americano. Alguns aspectos atuais. An. bras. Derm., 47: $247-252,1972$

12. ROSENBERG, F.R.; SANDERS, S. \& NELSON, C.T. - Pemphigus. A 20 year review of 107 patients treated with corticosteroids. Arch. Derm., 112: 962-970, 1976.

13. WANKE, N.C.F.; SILVA, M.M.; BRANDÃO, M.G. \& MACEIRA, J. - Tratamento de pênfigos: revisão de 31 casos. An. bras. Derm., 65: 119-122, 1990.

14. WOLF, R.; LEANDAU, M.; TUR, E. \& BRENNER, S. - Early treatment of pemphigus does not improve the prognosis. A review of 53 patients. J. Europ. Acad. Derm. Vener., 4: 123-130, 1995.

Received: 27 March 2000

Accepted: 14 September 2000 